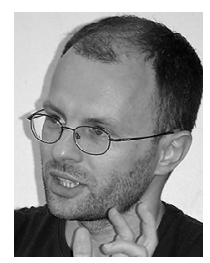

Artur Szutta •

\title{
PODMIOT MORALNY, MORALNE INTUICJE A HEURYSTYKI
}

\section{Stowa kluczowe emocje moralne, etyka cnót, heurystyki, intuicje moralne, sytuacjonizm, \\ Walter \\ Sinnott- -Armstrong}

\section{Streszczenie}

Tekst stanowi krytyczną analizę hipotezy stawianej przez Waltera Sinnotta-Armstronga, Liane Young i Fiery'ego Cushmana, zgodnie $z$ którą intuicje moralne to jedynie heurystyki afektywne. Po krótkiej prezentacji pojęcia heurystyki oraz argumentacji leżącej u podstaw przyjęcia hipotezy heurystyk, formułuję trzy kontrargumenty, $\mathrm{w}$ świetle których hipoteza heurystyk moralnych nie ma odpowiedniej motywacji epistemologicznej, opiera się na zbyt wąskim ujęciu intuicji moralnych oraz kontrowersyjnym akognitywnym ujęciu emocji moralnych. Dopełnienie tekstu stanowi zarys alternatywnej propozycji rozumienia intuicji moralnych. Proponowana poniżej argumentacja jest traktowana jako głos w sporze etyka cnót - sytuacjonizm, stanowiący argument na rzecz etyki cnót.

Spis treści

I. Intuicje moralne - ich miejsce w poznaniu moralnym

2. Heurystyki

3. Hipoteza heurystyk moralnych

4. Wątpliwości

5. Zarys alternatywnej koncepcji poznania moralnego

6. Wnioski 
$\mathrm{D}$ ebata między sytuacjonizmem a etyką cnót sprowadza się do sporu o to, czy podmiot, czy też zewnętrzne względem niego okoliczności ostatecznie determinują etyczne zachowanie. Nie są to jednak stanowiska znajdujące się na tej samej płaszczyźnie metodologicznej. Etycy cnót proponują pewien normatywny model cnotliwego podmiotu działania, który posiada dyspozycje do niezawodnego czynienia tego, co jest moralnie dobre w danych okolicznościach, zaś sytuacjonistyczni krytycy etyki cnót formułują tezy opisowe, w świetle których nasze moralne zachowanie może być wyjaśnione przez odwołanie się nie do cnót, czy też moralnego charakteru, ale do różnorakich pozapodmiotowych czynników sytuacyjnych, które determinują nasze moralne oceny, wybory i działania. Niemniej, pomimo tego, że oba stanowiska reprezentują odmienne podejścia do zagadnienia moralnej podmiotowości człowieka, normatywne i opisowe, można precyzyjnie zakreślić płaszczyznę sporu między nimi.

Etycy cnót, chociaż proponują normatywną koncepcję cnoty, to formułują ją na podstawie pewnych opisowych założeń dotyczących ludzkiej podmiotowości (moralnej sprawczości i moralnego poznania), mianowicie zakładają, że istotne czynniki determinujące nasze moralne oceny, decyzje czy zachowanie mają swoje źródło w naszych zdolnościach poznawczych i sprawczych. Czyli, jeśli proponują pewien idealny model osoby cnotliwej, na przykład posiadającej kardynalne cnoty roztropności, sprawiedliwości, męstwa i umiarkowania, to zakładają, że realni ludzie są w stanie przynajmniej przybliżać się do tego ideału, to znaczy, że posiadają przynajmniej jakąś dającą się rozwijać namiastkę zdolności do poznania tego, co jest w danych okolicznościach moralnie słuszne, oraz jakiś poziom efektywnego wewnętrznego umotywowania i autodeterminacji do działania zgodnego z rozpoznaniem tego, co moralnie słuszne. Tak więc etycy cnót czynią przynajmniej dwa opisowe założenia dotyczące kondycji ludzkiej, konieczne do formułowania normatywnej etyki cnót: osoby ludzkie są zdolne do poznania moralnego oraz posiadają zdolność kierowania się tym poznaniem w podejmowaniu decyzji i w działaniu. 
Sytuacjonistyczna krytyka etyki cnót jest wymierzona w oba te założenia. W wersji skrajnej polega ona na całkowitej ich negacji, w wersji umiarkowanej nie przeczy istnieniu możliwości poznania moralnego i opartej na nim motywacji, ale wskazuje na istnienie innych jeszcze czynników determinujących ludzkie działanie, które mają na tyle przemożny wpływ na to $\mathrm{d} z$ iałanie, że owe podmiotowe zdolności ostatecznie okazują się nieefektywne, przez co stają się nieistotne w wyjaśnieniu ludzkich zachowań.

W niniejszym artykule skupię się tylko na jednym aspekcie powyżej zarysowanej płaszczyzny sporu - na możliwości poznania moralnego, którym w sposób autonomiczny można by się kierować $\mathrm{w}$ moralnym działaniu. Jednakże i ten aspekt nie zostanie tutaj ujęty całościowo. W ramach kwestii poznania moralnego skupię się jedynie na problemie moralnych intuicji i to tylko w wąskim ujęciu. Pytanie, które tutaj stawiam, brzmi: czy moralne intuicje są tylko pewną formą heurystyki, czy też posiadają wartość kognitywną analogiczną do tej przypisywanej intuicjom w matematyce czy epistemologii?

W świetle najnowszych badań w ramach psychologii moralnej stawiana jest często hipoteza, że nasze intuicje moralne to jedynie efekt zastosowania przez nasze mózgi heurystyki podstawiania, heurystyki afektywnej w szczególności'. Jeśli byłaby to prawda, zwolennicy sytuacjonizmu mieliby do dyspozycji mocny argument przeciwko jednemu z centralnych założeń etyki cnót, że posiadamy zdolność moralnego poznania w określonych sytuacjach. Wynika to $z$ faktu, że moralne intuicje wydają się podstawą wszelkiego poznania moralnego i jeśli nie miałyby charakteru poznawczego wglądu w moralną rzeczywistość, a były jedynie nieistotnymi od strony poznawczej sposobami motywowania nas do działania, to powinny być interpretowane raczej jako czynnik

Taką hipotezę stawiają np. C.R. Sunstein, Moral Heuristics, „Behavioral and Brain Science" 28 (2005), s. 53I-573; J. НAIDT, The Emotional Dog and Its Rational Tail, „Psychology Review” I08 (200I), s. 8I4-834; czy W. Sinnott-Armstrong, L. Young, F. Cushman, Moral Intuitions [w:] J.M. Doris i the Moral Psychology Research Group (eds.), The Moral Psychology Handbook, Oxford 2010, s. 246-272. 
sytuacyjny niż podmiotowy, który sprawia, że nie my jako podmioty moralne, ale zewnętrzna względem naszej podmiotowości sytuacja determinuje nasze działanie, w tym oceny i decyzje moralne.

Celem niniejszego artykułu będzie zatem krytyczna ocena hipotezy, że intuicje moralne to jedynie afektywne heurystyki. Cel ów osiągnę, podejmując następujące kroki. Zacznę od ogólnej charakterystyki intuicji moralnych oraz ich miejsca w epistemologii moralnej leżącej u podstaw etyki cnót. Następnie poddam analizie pojęcie heurystyki, aby potem zaprezentować hipotezę wraz ze wspierającymi ją argumentami, że intuicje moralne to heurystyki afektywne. Paradygmatycznym przykładem tej hipotezy i argumentów będzie dla mnie stanowisko Waltera Sinnotta -Armstronga, wyrażone przez niego i jego kolegów, Liane Young i Fiery'ego Cushmana, w artykule Moral Intuitions ${ }^{2}$. Następnie zaproponuję trzy argumenty wskazujące na fałszywość tezy sprowadzającej intuicje moralne do kategorii heurystyk. Po pierwsze, będę argumentował, że hipoteza heurystyk wymaga odpowiedniej motywacji, na przykład uzasadnionego przekonania, że intuicje moralne prowadzą do systematycznych błędów, warunek ten jednak nie jest w przypadku intuicji moralnych spełniony. Po drugie, będę się starał pokazać, że koncepcja intuicji moralnych proponowana przez Sinnotta-Armstronga i jego kolegów jest zbyt wąska - pomija się w niej inne rozumienia (lub rodzaje) intuicji moralnych. Po trzecie, postaram się pokazać, że istnieją powody, aby odmiennie niż autorzy heurystycznej hipotezy rozumieć emocje moralne. Dla autorów Moral Intuitions emocje moralne, mające decydujący wpływ na kształt intuicji moralnych, nie mają charakteru kognitywnego, tymczasem istnieją racje, aby traktować emocje jako efekt procesów kognitywnych. Pewnym dopełnieniem wymienionych powyżej argumentów będzie zarys alternatywnej względem hipotezy afektywnych heurystyk koncepcji poznania moralnego, która mogłaby rościć sobie pretensje do większej mocy eksplanacyjnej. Dopełnienie to stanowiłoby tym samym pewien kontrargument wobec twierdzenia, że hipoteza heurystyk afek-

Tamże. 
tywnych posiada relatywnie największą zdolność do wyjaśnienia obserwowanych w trakcie eksperymentów faktów dotyczących formułowania sądów moralnych.

\section{Intuicje moralne - ich miejsce w poznaniu moralnym}

Jeśli usłyszymy od kogoś, że (w danych okolicznościach) powinniśmy uczynić to a to, np. powinniśmy powiedzieć prawdę przyjacielowi dotyczącą złego postępowania jego dziecka, zawsze nasuwają się pytania: „Skąd to wiesz? Dlaczego powinienem uznać, że jest tak, jak mówisz?". Osoba próbująca nas przekonać będzie odwoływać się do już uznanych przez nas prawd, z których taka powinność mogłaby wynikać: „przecież sam mówiłeś, że lepiej usłyszeć prawdę, niż żyć w iluzji!". Jeśli jednak ta strategia zawie$\mathrm{d} z i e$, pozostaje odwołanie się do naszych intuicji.

Istnieje cała gama propozycji ujęcia intuicji moralnych. Przez intuicję moralną można rozumieć mechanizm poznawczy lub proces poznawczy, stan mentalny bądź stanowiące wynik tego procesu, czy też oparte na owym stanie mentalnym przekonanie lub sąd moralny. W zależności od koncepcji, różni autorzy, wskazują na różne z powyżej wymienionych alternatyw: dla Roberta Audiego na przykład (i tzw. nurtu racjonalistycznego intuicjonizmu etycznego) intuicja moralna oznacza takie twierdzenie moralne, którego zrozumienie wystarcza, aby być w sposób uzasadniony przekonanym o jego prawdziwości ${ }^{3}$. Zdaniem innych, na przykład Michaela Huemera, czynimy to w oparciu o fenomenalne prezentacje intelektualne (seemings) ${ }^{4}$. Zdaniem jeszcze innych w opar-

3 Audi na temat intuicji moralnych pisze w wielu miejscach. Najbardziej znana jego praca dotyczaca intuicjonizmu etycznego to The Good in the Right. The Theory of Intuition and Intrinsic Value, Princeton 2004. Określenie intuicji zaproponowane powyżej podaję za jego artykułem Intuition, Inference, and Rational Disagreement in Ethics, "Ethical Theory and Moral Practice” II (2008), s. 475-492.

4 Por. M. Huemer, Ethical Intuitionism, Basingstoke-New York 2005, rozdz. 5. 
ciu o swoiście rozumianą percepcję moralną, w której własności moralne danej sytuacji prezentują się nam analogicznie do jakości zmysłowych ${ }^{5}$. Są też tacy, którzy sprowadzają intuicje moralne do emocji moralnych ${ }^{6}$. Możliwych ujęć intuicji jest wiele, niemniej, zwolenników szeroko rozumianego intuicjonizmu moralnego łączy przekonanie, że intuicyjny sąd moralny nie jest wywiedziony logicznie $z$ innych twierdzeń oraz będąc sądem intuicyjnym, rację uzasadniającą zawiera on w sobie (jeśli jest utożsamiony $z$ intuicją) lub w leżącej u podstaw jego przyjęcia intuicji

Intuicje moralne pełnią zatem rolę źródła wiedzy moralneje, koniecznego elementu, do którego odwołanie się pozwala uniknąć zarzutu arbitralności naszych przekonań moralnych czy problemów nieskończonego regresu lub błędnego koła. Jeśli zatem przyjmiemy, że osoba cnotliwa musi dysponować wiedzą moralną ${ }^{9}$ aby móc się

5 Takiego stanowiska broni na przykład J.P. McBrayer w artykule A Limited Defense of Moral Perception, „Philosophical Studies” I49 (2010), s. 305-320.

6 Por. np. S. Roeser, Moral Emotions and Intuitions, Basingstoke-New York 20I I.

7 Krytyk intuicjonizmu może inaczej rozumieć intuicje moralne. Na przykład Walter Sinnott-Armstrong twierdzi, że intuicje moralne jedynie wydają się niewywnioskowane $z$ innych przekonań, podczas gdy w rzeczywistości mogą być wynikiem nieuświadomionych rozumowań. Zob. Reflections on Reflection in Robert Audi's Moral Intuitionism [w:] M. Timmons, J. Greco, A.R. Mele (eds.) Rationality and the Good. Critical Essays on the Ethics and Epistemology of Robert Audi, Oxford 2007, s. 19-30.

8 Twierdzenie to nie odnosi się jedynie do stanowisk fundacjonalistycznych, ale także pewnych wersji koherentyzmu, gdzie przyjmuje się jakiś minimalny poziom wiarygodności intuicji etycznych, ale stawia warunek ich koherencji z innymi intuicjami moralnymi, przy spełnieniu którego to warunku można dopiero intuicjom przypisywać wystarczający poziom wiarygodności, aby uznać, że przekonania moralne oparte na takich intuicjach zasługują na miano uzasadnionych. Taki intuicjonistyczny koherentyzm zdaje się głosić David Brink (zob.jego Moral Realism and the Foundations of Ethics, Cambridge 1989, szczególnie rozdz. 5).

9 Zakładam tutaj pewne rozumienie etyki cnót, mianowicie takiej, jaka przyjmuje realizm etyczny, tj. zakłada, że istnieją obiektywne prawdy etyczne (i w związku z tym niezależne od jednostek, kultur itd. są ich warunki prawdziwości). Można bronić antyrealistycznej wersji etyki cnót, w ramach której przyjmuje się na przykład, że prawdy moralne są określone (konstruowane) kulturowo bądź w ramach jakiegoś gatunku, i wówczas twierdzić, że intuicje moralne nie muszą stanowić źródła obiektywnego poznania moralnego. Niemniej, nawet w takim przypadku wydaje się, że konieczne jest założenie, że podmiot umie świadomie identyfikować podstawowe (choć kulturowo czy gatunkowo skon- 
nią kierować w swoich decyzjach i działaniu moralnym, oraz warunkiem koniecznym takiej wied zy jest posiadanie wiarygodnych intuicji moralnych, wówczas staje się jasne, że wiarygodność intuicji stanowi niezbędne założenie etyki cnót. Podważenie tej wiarygodności stanowiłoby mocny argument na rzecz stanowiska sytuacjonistycznego.

\section{Heurystyki}

Zanim przejdziemy do charakterystyki stanowiska, zgodnie z którym intuicje moralne miałyby być jedynie heurystykami afektywnymi, kilka słów na temat samego pojęcia heurystyki. Ogólnie ujmując, heurystyki to nieświadomie stosowane tzw. zasady kciuka, które pomagają nam osiągać wielorakie cele praktyczne w życiu. Przez „zasadę kciuka” rozumiem uproszczoną zasadę rozumowania bądź postępowania ${ }^{10}$, w którym nie identyfikujemy właściwych relacji, nie kierujemy się prawidłowo odczytanymi zależnościami między poznawanymi przedmiotami, ale idziemy na skróty, kierując się nieistotnymi z punktu widzenia ujęcia właściwego przedmiotu poznania wskazówkami, które jednak jakoś wydają się być z tym przedmiotem powiązane. Podobną strategię stosują dzieci, które formułując sądy na temat dobra lub zła moralnego, identyfikują dobro czy zło nie na mocy zrozumienia ich natury, ale postępując zgodnie ze wskazówkami rodziców, które uznają często za czynniki konstytuujące moralny obowiązek: „Dobre lub powinne jest to, co moi rodzice wskażą jako dobre lub powinne"ll.

struowane) prawdy etyczne, którymi będzie kierował się w swoich moralnych decyzjach i działaniu, co sprawia, że tego rodzaju etyka cnót także stoi w obliczu konieczności obrony wiarygodności (chociaż specyficznie rozumianych) intuicji etycznych (bądź jakiejś alternatywnej formy „poznania moralnego”) w dyskusji ze zwolennikami sytuacjonizmu.

10 Jako „zasadę kciuka” charakteryzuje heurystykę C.R. Sunstein (zob, tegoż Moral Heuristics, dz.cyt.), zaś jako "uproszczoną regułę wnioskowania” ujmuje ją P. Szymczak, tłumacz polskiego wydania książki D. Kannemana, Pułapki myślenia. O myśleniu szybkim $i$ wolnym, Poznań 20I2, s. I5.

11 Nie każde postępowanie według tej strategii zasługuje na miano heurystyki. O heurystyce mówimy w przypadku nieświadomego stosowania tej strategii. 
W zwyczajnych okolicznościach strategie heurystyczne są efektywne, niemniej w sytuacjach nietypowych często zawodzą i sprawiają, że popełniamy systematyczne błędy ${ }^{12}$. Można wymienić wiele rodzajów heurystyk. W literaturze przedmiotu najczęściej wymienia się przykłady heurystyki dostępności i heurystykę reprezentatywności. W pierwszym przypadku heurystyka polega na tym, że w trakcie podejmowania decyzji czy próby odpowiedzi na jakieś pytanie polegamy na łatwości, z jaką przywołujemy w pamięci odpowiednie przykłady. Na przykład na pytanie, które miasto jest większe, San Diego czy Waszyngton, możemy, polegając na tym, że łatwiej nam przywołać w pamięci przykłady, kiedy słyszeliśmy nazwę stolicy USA, niż nazwę miasta znad granicy z Meksykiem, wskazać Waszyngton jako większe miasto, gdy tymczasem jest odwrotnie. Heurystyka reprezentatywności natomiast, często stosowana przy rozwiązywaniu problemów związanych $z$ szacowaniem prawdopodobieństwa, polega na kierowaniu się przy odpowiedzi na pytanie o prawdopodobieństwo nie samą ideą prawdopodobieństwa, ale nieświadomie za nią podstawioną ideą reprezentatywności - na przykład oszacowując prawdopodobieństwo, że jakaś osoba, np. Linda, inteligentna trzydziestolatka, po studiach filozoficznych, aktywna w sprawach społecznych, wykonuje określony zawód. Kierując się heurystyką reprezentatywności badane przez psychologów osoby często uznają za bardziej prawdopodobne, że Linda jest pracownicą banku i działaczką feministyczną niż tylko pracownicą banku. Taka odpowiedź stoi w wyraźnej sprzeczności z logiką i zasadami prawdopodobieństwa, ponieważ zbiór możliwości pracy w banku w ogóle obejmuje podzbiór możliwości jednoczesnej pracy w banku i wykonywania dodatkowych czynności, takich jak udział w ruchu feministycznym. Niemniej charakterystyka Lindy bardziej odpowiada opisowi osoby, która jest zaangażowana w działalność feministyczną. Coś nam mówi, że to niemożliwe, aby Linda była tylko pracownicą banku' ${ }^{13}$.

\footnotetext{
12 Zob. C.R. Sunstein, Moral Heuristics, dz. cyt., s. 53I-573.

13 Przykład Lindy podaję za D.G. Mrers, Intuicja. Jej sita i słabość, tłum. A. Sosenko,

Wrocław 2004, s. 203.
} 
Wszystkie heurystyki mają wspólną cechę: polegają na nieuświadomionym zastępowaniu cechy docelowej inną cechą - tzw. cechą podstawioną, i rozwiązywaniu problemu dotyczącego tej pierwszej $z$ wykorzystaniem analiz i kalkulacji dotyczących tej drugiej. Trafnie tę strategię scharakteryzowali Daniel Kahneman i Shane Frederic, według których $z$ heurystyką mamy do czynienia, "gdy stojąc w obliczu trudnego pytania, odpowiadamy na inne łatwiejsze pytanie, często nie zdając sobie nawet sprawy z tej podmiany pytań"14. Proces wykorzystujący strategie podstawiania zachodzi w sposób bezwysiłkowy i automatyczny, utrudnia jego wykrycie i często wymaga refleksji i krytycznego namysłu.

Zjawisko heurystyki jest wyjaśniane w ramach tzw. modelu dwuprocesowego umysłu ${ }^{15}$. W świetle tego modelu nasz umysł składa się z dwóch silnie ze sobą skorelowanych podsystemów, tzw. systemu I i systemu 2. System I to zbiór modułów, procesów poznawczych, które działają automatycznie, szybko i bez świadomego wysiłku ze strony podmiotu poznającego. Rezultaty działań tego systemu określane są mianem intuicji. System 2 to zbiór procesów poznawczych, które są powolne, podlegają świadomej kontroli oraz wymagają wysiłku i uwagi. W sytuacjach poznawczego nadmiaru (np. gdybyśmy jednocześnie próbowali czytać książkę, słuchać radia i jeszcze prowadzić rozmowę przez telefon) praca systemu 2 ulega pogorszeniu, popełnia on błędy lub nawet załamuje się jego funkcjonowanie. Pracę systemu 2 określa się mianem rozumowania, które często sprowadza się do kontrolowania uwagi i krytycznego porównywania wyników procesów przesyłanych z systemu I. Heurystyki zgodnie z modelem dwuprocesowym to domena systemu $\mathrm{I}^{16}$.

14 Zob. D. Kahneman, F. Shane, A Model of Heuristic Judgment [w:] K. Holyoak, R.G. Morrison (eds.), The Cambridge Handbook of Thinking and Reasoning, Cambridge 2005, s. 267-292.

15 Za orędowników tego modelu uchodzą Daniel Kahneman i Amos Tverski. Więcej na temat tego modelu w niniejszym tomie pisze Natasza Szutta, Empiryczna adekwatność Arystotelesowskiej mądrości praktycznej, s. 190-193. 


\section{Hipoteza heurystyk moralnych}

Sinnott-Armstrong, Young i Cushman w artykule Moral Intuitions stawiają hipotezę, że moralne intuicje dadzą się najlepiej wyjaśnić właśnie jako przykłady heurystyk ${ }^{17}$. Uważają oni, że przyjęcie takiej hipotezy wymaga wykazania, iż spełnione są dwa warunki: a) cecha docelowa musi być niedostępna (lub przynajmniej trudno dostępna), natomiast cecha podstawiona łatwo dostępna; b) heurystyki muszą być bezwysiłkowe, automatyczne i nieuświadomione. Autorzy Moral Intuitions twierdzą, że warunki te są spełnione w przypadku intuicji moralnych.

Do wniosku, że cecha dobra moralnego (którą w przypadku moralnego poznania należy uznać za docelową cechę, której dotyczą sądy moralne) jest niedostępna poznawczo, autorzy dochodzą na podstawie analizy głównych teorii etycznych. Ich zdaniem, chociaż teorie deontologiczne, utylitaryzm czy kontraktualizm podają definicje dobra (bądź obowiązku) moralnego, są to jedynie abstrakcyjne określenia, które nie pozwalają na identyfikację dobra w konkretnych okolicznościach. Jak twierdzą, nie można (a przynajmniej nie jest to łatwe) zidentyfikować działania, które będzie maksymalizowało przyjemność, dającej (lub niedającej) się uniwersalizować maksymy, albo określić, które działanie uznane zostałoby przez bezstronnych racjonalnych obserwatorów za złe. Także stanowiska takie jak moralny relatywizm czy subiektywizm nie są zdaniem Sinnotta-Armstronga i jego kolegów pomocne w identyfikacji dobra czy zła moralnego. Niełatwo, jak piszą, określić, czy dany partykularny sąd (konwencja) jest słuszny, czy nie. Subiektywizm jest niesatysfakcjonujący (ta uwaga dotyczy także relatywizmu), ponieważ $\mathrm{w}$ ogóle nie jest w stanie objąć sporów międzyosobowych ani ująć cech dobra lub zła moralnego w obiektywistyczny sposób.

Skoro cechy docelowe dobra i zła moralnego nie są dostępne, to powstaje miejsce na wysunięcie hipotezy heurystyki. Zanim autorzy podejmą się pokazania, że i drugi z powyżej zarysowa-

17 W. Sinnott-Armstrong, L. Young, F. Cushman, Moral Intuitions, dz. cyt. 
nych warunków jest spełniony (tj., że intuicje moralne powstają w sposób bezwysiłkowy, automatyczny i nieświadomy), proponują rozważania dotyczące najlepszych kandydatów na cechę heurystyczną (którą w ramach moralnych heurystyk podstawiamy nieświadomie zamiast docelowej cechy dobra lub zła moralnego). Najbardziej obiecującą alternatywą wydają się im emocje (afekty), takie jak lęk, gniew, pogarda, odraza czy radość. Formułowanie intuicyjnych sądów moralnych polegałoby zatem ich zdaniem na nieświadomym myleniu doświadczania stanów afektywnych $z$ widzeniem własności moralnych. Heurystyki afektywne polegałyby na następującej regule: „Jeśli myślenie o danym działaniu sprawia, że czujesz się dobrze albo źle, wówczas oceniaj je jako dobre albo złe, w zależności od tego, jak się czujesz".

Ujmowanie intuicji moralnych w kategoriach heurystyk afektywnych znajduje zdaniem autorów potwierdzenie w licznych badaniach empirycznych, które pokazują między innymi, że spełniony jest drugi warunek prawdziwości hipotezy heurystyk moralnych. Po pierwsze, liczne eksperymenty pokazują wysoki poziom korelacji pomiędzy sądami moralnymi a emocjami ${ }^{18}$, po drugie w świetle wielu badań emocje kształtują nasze sądy moralne ${ }^{19}$. Istnieją także badania, które pokazują, że sam proces pod-

18 Zob. na przykład D. Kahneman i in., Shared Outrage and Erratic Rewards: The Psychology of Punitive Damages, "Journal of Risk and Uncertainty" I6 (I998), s. 49-86; K. CARlsmith i in., Why Do We Punish? Deterrence and Just Deserts as Motives for Punishment, ,Journal of Personality and Social Psychology” 83 (2002), s. 284-289 (podaję za W. Sinnott-Armstrong i in., Moral Intuitions, dz.cyt.).

Zob. T. Wheatley, J. НAidt, Hypnotic Disgust Makes Moral Judgments More Severe, „Psychological Science” I6 (2007), s. 780-784; S. Schnall, J. Haidt, G. Clore, A. Jordan, Disgust as Embodied Moral Judgment, „Personality and Social Psychology Bulletin" 34 (2008), s. I096-II09; J.D. Greene i in., Cognitive Load Selectively Interferes with Utilitarian Moral Judgment, „Cognition" I07 (2008), s. II44-II54; P. Valdesolo, D. DeSteno, Manipulations of Emotional Context Shape Moral Judgments, „Psychological Science” I7 (2006), s. 476-477; M.F. Mendez, E. Anderson, J.S. Shapira, An Investigation of Moral Judgment in Frontotemporal Dementia, "Cognitive Behavioral Neurology” I8 (2005), s. I93-I97; M. Koenigs i in., Damage to the Prefrontal Cortex Increases Utilitarian Moral Judgments, „Nature” 446 (2007), s. 908-9iI; E. Ciaramelli $\mathrm{i}$ in., Selective Deficit in Personal Moral Judgment Following Damage to Ventromedial Prefrontal Cortex, „Social Cognitive Affective Neuroscience” 2 (2007), s. 84-92 (podaję za W. Sinnott-Armstrong i in., Moral Intuitions, dz. cyt.). 
stawiania poznania moralnego przez emocje jest podświadomy ${ }^{20}$, chociaż, jak zastrzegają autorzy Moral Intuitions, istnieje w tym obszarze potrzeba dalszych badań.

Przyznają oni także, że ich hipoteza stoi w obliczu pewnych trudności, którym będzie musiała stawić czoła. Po pierwsze, heurystyki pozamoralne są o wiele łatwiej identyfikowalne niż heurystyki moralne. W opisanym powyżej przypadku Lindy, w którym osoby wskazują na większe prawdopodobieństwo, że jest ona pracownicą banku i działaczką feministyczną niż tylko pracowniczką banku, o wiele łatwiej uzasadnić twierdzenie, że mamy do czynienia $z$ heurystyką niż w przypadku sądów moralnych. Jednym z głównych powodów, dla których stawiamy hipotezę heurystyki, jest wyjaśnienie, że sądy dotyczące prawdopodobieństwa są błędne, zaś hipoteza heurystyk pozwala nam zrozumieć, dlaczego tego typu błąd został popełniony. W przypadku sądów moralnych tego typu wyjaśnienie nie jest oczywiste, ponieważ nie ma pewności, czy dany sąd moralny jest rzeczywiście błędny. Po drugie, autorzy są także świadomi, że badania, na które się powołują, dotyczą jedynie pewnego podzbioru intuicji moralnych, wierzą jednak, że ich projekt jest obiecujący i posiada moc wyjaśniającą, która prima facie pozwala przyjąć ich hipotezę.

Jak podkreślają, hipoteza heurystyki atrybucji afektywnej najlepiej wyjaśnia, dlaczego zdroworozsądkowe zasady moralne są do obalenia, dlaczego tak trudno jest określić, kiedy zdroworozsądkowe zasady moralne zostają obalone, oraz dlaczego ludzie zdają się odpowiadać na skomplikowane pytania etyczne tak zaskakująco szybko. Ponadto, co autorzy uznają za mocną stronę swojego stanowiska, hipoteza heurystyki atrybucji afektywnej nie wymaga

20 Zob. na przykład M. Hauser, L. Young, F. Cushman, Reviving Rawls' Linguistic Analogy: Operative Principles and the Causal Structure of Moral Action [w:] W. Sinnott-Armstrong (ed.), Moral Psychology, Volume 2: The Cognitive Science of Morality, Cambridge, MA 2008, s. 107-I43; F. Cushman, L. Young, M. Hauser, The Role of Conscious Reasoning and Intuition in Moral Judgments: Testing Three Principles of Harm, „Psychological Science” I7 (2006), s. 1082-I089; J. Miknail, Aspects of a Theory of Moral Cognition: Investigating Intuitive Knowledge of the Probibition of Intentional Battery and the Principle of Double Effect, 2002, ssrn.com/abstracts $=762385$ (za W. SinnotT-Armstrong i in., Moral Intuitions, $\mathrm{dz}$. cyt.). 
założenia moralnego realizmu, że istnieją obiektywne, niezależne od nas własności moralne, a także jest spójna $z$ teorią ewolucji. Pozwala bowiem zrozumieć, w jaki sposób nasze intuicje moralne (rozumiane afektywnie) motywują nas do zachowań adaptacyjnych koniecznych do przetrwania, bez konieczności uznania, że pojęcia moralne (czy terminy użyte w sądach moralnych) reprezentują jakieś moralne własności.

Przyjęcie hipotezy heurystyki atrybucji afektywnej zdaniem autorów Moral Intuitions ma poważne konsekwencje filozoficzne. Po pierwsze, jeśli moralne intuicje to jedynie heurystyki afektywne, wówczas nie mogą one dłużej uchodzić za bezpośrednie wglądy we własności moralne. Taki wniosek, zdaniem autorów, stanowiłby zabójczą konsekwencję dla intuicjonizmu moralnego, a także trudność dla moralnego kognitywizmu w ogóle. Po drugie, wyjaśnienie heurystyczne podkopałoby wiarygodność intuicji moralnych, szczególnie jeśli chodzi o sytuacje nietypowe. To $z$ kolei prowadzi do trzeciej konsekwencji, w istotny sposób odnoszącej się do krytyki utylitarystycznej zasady maksymalizacji. Liczni krytycy tej zasady odwołują się w swoich próbach obalenia utylitaryzmu do naszych moralnych intuicji, formułując liczne intuicyjne kontrprzykłady. Jeśli kontrprzykłady te są oparte na zawodnym źródle, które ostatecznie okazuje się jedynie mechanizmem heurystycznym, wówczas należy odrzucić same krytyki odwołujące się do tych kontrprzykładów. Tak więc, jak zauważają Sinnott-Armstrong, Young i Cushman, ich hipoteza heurystyki atrybucji afektywnej ma dalekosiężne i poważne konsekwencje. Kolejna $z$ nich, można dodać, to oczywiście wzmocnienie stanowiska sytuacjonizmu w sporze $z$ etyką cnót. Waga, jaką dla moralnej epistemologii i sporu $z$ sytuacjonizmem posiada hipoteza heurystyk moralnych, stanowi dodatkową motywację do tego, aby krytycznie przyjrzeć się stanowisku Sinnotta-Armstronga i jego kolegów, co będę się starał uczynić w dalszej części niniejszego artykułu.

Zanim jednak przejdziemy do następnego punktu, konieczna będzie pewna klaryfikacja hipotezy heurystyki atrybucji afektywnej. Można bowiem zastanawiać się, czy dotyczy ona wszystkich 
intuicji moralnych, czy też tylko pewnego ich podzbioru?21 Wydaje się, że w świetle tego, jak jej orędownicy prezentują jej filozoficzne konsekwencje, należy przyjąć wersję globalną hipotezy heurystyk moralnych, tj. że obejmuje ona wszystkie intuicje moralne. Gdyby tak nie było, jej autorzy uznaliby, że niektóre intuicje moralne, które nie okazałyby się heurystykami, wciąż mają prawo pretendować do tego, że są wiarygodne i stanowią bezpośrednie uchwycenie prawd moralnych, oraz że przynajmniej te intuicje (niebędące heurystykami) nadal mogą stanowić podstawę krytyki stanowiska utylitarystycznego.

\section{Watpliwości}

\subsection{Jak zidentyfikować błędne intuicje moralne?}

Hipoteza heurystyk pozamoralnych powstała wskutek odkrycia, że ludzie popełniają błędy poznawcze. Oszacowując jako większe prawdopodobieństwo, że Linda jest pracownicą banku i aktywistką feministyczną, niż że jest ona tylko pracownicą banku, badani popełniali w sposób wyraźny błąd logiczny (lub przynajmniej źle interpretowali opis sytuacji Lindy). Także w przypadku identyfikacji większego miasta odpowiedzi badanych łatwo skonfrontować $z$ faktami i pokazać błędność przekonania, że Waszyngton jest większy od San Diego. Taką możliwością falsyfikacji intuicyjnych przekonań moralnych nie dysponujemy, jeśli uznamy, że wszystkie intuicje moralne są wynikiem heurystyk. Jest tak, ponieważ wówczas brakuje nam punktu odniesienia, na podstawie którego moglibyśmy orzec, że dane intuicyjne sądy moralne są fałszywe. Skoro tak, to jakie moglibyśmy mieć uzasadnienie dla stawiania samej hipotezy heurystycznej w kontekście intuicji moralnych?

21 Stanowisko, zgodnie $z$ którym tylko niektóre intuicje moralne są wynikiem działania heurystyk, głosił na przykład C.R. Sunstein (zob. tenże, Moral Heuristics, dz.cyt.). 
Sinnott-Armstrong i jego koledzy, przynajmniej w omawianym tu tekście, zdają się dostrzegać ten problem, przyznając, że heurystyki pozamoralne są o wiele łatwiej identyfikowalne niż heurystyki moralne. Nie dostrzegają jednak, że przyjmując globalną wersję hipotezy heurystyk moralnych, pozbawiają się możliwości odróżnienia prawdziwych przekonań moralnych od przekonań fałszywych ${ }^{22}$. Postulowanie hipotezy heurystycznej wymaga dysponowania kryterium identyfikowania fałszywych twierdzeń etycznych. Fałszywość tę można stwierdzić jedynie w świetle porównania $z$ innymi twierdzeniami etycznymi, do których prawdziwości mamy uzasadnione przekonanie. Jeśli przyjmiemy, że wszystkie przekonania moralne mają swoje źródło w moralnych intuicjach, zaś wszystkie moralne intuicje są heurystykami, to stoimy w obliczu niemożności uzasadnienia jakiegokolwiek przekonania moralnego. To $z$ kolei pozbawia nas możliwości wykazania, że określone intuicyjne przekonanie moralne ma heurystyczną genezę. Tak więc globalna hipoteza heurystyk moralnych wydaje się samoznosząca.

Rozwiązaniem powyższego problemu mogłoby być uznanie, że istnieją pewne pośrednie drogi wykazania, że wszystkie intuicje moralne są fałszywe, zaś hipoteza heurystyk moralnych byłaby tylko wyjaśnieniem tego, jak to się dzieje, że posiadamy takie fałszywe przekonania moralne. Postawienie diagnozy o globalnej fałszywości intuicji moralnych byłoby możliwe na przykład w oparciu o teorię błędu ${ }^{23}$. Wówczas autorzy hipotezy heurystyki

22 Oczywiście, powyższa uwaga sama jest oparta na pewnym założeniu, mianowicie, że jedynym niezależnym źródłem wiedzy moralnej są moralne intuicje. Zwolennicy globalnej hipotezy heurystyk moralnych mogliby twierdzić, że wiedza moralna jest możliwa, ponieważ ma swoje źródło nie w intuicjach moralnych, ale innych podstawach. Wówczas jednak ciężar dowodu leżałby po stronie zwolenników istnienia takiego alternatywnego źródła wiedzy moralnej. Przynajmniej prima facie wydaje się, że takiego alternatywnego dla moralnych intuicji źródła wiedzy moralnej, ze względu na konieczność uzasadnienia przekonań moralnych, nie ma. Chyba że przyjmiemy istnienie innego jeszcze rodzaju intuicji moralnych niż te oparte na emocjach, o czym w następnym zarzucie.

23 Argumentację na rzecz teorii błędu, głoszącej, że wszystkie nasze przekonania moralne są fałszywe, proponuje John Mackie (zob, tenże, Etbics. Inventing Right and Wrong, London 1977). 
staliby przed innym problemem, $z$ którym jednak można by sobie poradzić. Musieliby pokazać, jaką funkcję spełniają heurystyki moralne. Otóż, w ramach ogólnej koncepcji heurystyk twierdzi się, że w normalnych okolicznościach często okazują się spełniać swoje zadanie, czyli na przykład pozwalają dość trafnie określać prawdopodobieństwo pewnych zdarzeń czy oszacowywać rozmiary miast. Jeśli natomiast wszystkie przekonania moralne byłyby fałszywe, to jak wówczas rozumieć przydatność intuicji moralnych w „normalnych warunkach”? Wydaje się, że zwolennicy globalnej hipotezy heurystyk moralnych mogą przyjąć akognitywistyczną interpretację intuicji moralnych, jako ewolucyjnie wypracowanych afektywnych motywatorów do działań, które w normalnych okolicznościach służą naszemu przetrwaniu.

Przyjęcie teorii błędu oraz odwołanie się do ewolucyjnego wyjaśnienia genezy moralnych intuicji stanowi pewne rozwiązanie problemu motywacji hipotezy heurystyk afektywnych. Stanowisko takie jednak wymaga dalszej argumentacji i wikła w debatę pomiędzy realizmem etycznym a teorią błędu. Ze względu na ograniczone ramy tego artykułu założę, że nie jest to rozwiązanie zadowalające ani dla zwolenników hipotezy heurystyk afektywnych (nawet w wersji globalnej), ani tym bardziej zwolenników moralnego intuicjonizmu. Podobnie takie rozwiązanie nie zadowalałoby żadnej ze stron w debacie pomiędzy etykami cnoty a zwolennikami sytuacjonizmu. Tak więc, jeśli Sinnott-Armstrong $i$ jego koledzy nie chcą przyjąć antyrealizmu etycznego lub sceptycyzmu, tj. uznają, że przynajmniej niektóre twierdzenia mogą w sposób uzasadniony zostać uznane za prawdziwe, powinni zarzucić globalną wersję hipotezy heurystyk afektywnych.

\subsection{Wąskie rozumienie intuicji}

Zgodnie z kolejnym zarzutem, które można postawić zwolennikom globalnej tezy heurystyk moralnych, ujmują oni intuicje moralne zbyt wąsko, nie pozostawiając miejsca na intuicje innego rodzaju niż te uwarunkowane emocjonalnymi reakcjami. W literaturze przedmiotu można znaleźć propozycje rozumienia intuicji moral- 
nych, które nie mieszczą się w schemacie czysto emocjonalnie uwarunkowanych reakcji, wskazują bowiem na element racjonalny (rozumowy) w poznaniu moralnym. Autorzy tacy jak Henry Sidgwick, David. W. Ross, Robert Audi czy Philip Stratton-Lake, aby wymienić tylko niektórych, rozumieją intuicje moralne jako rezultat (lub sam akt) intelektualnego wglądu lub zrozumienia, które w swojej naturze są bliższe wglądom matematycznym niż heurystykom. Tak oto na przykład Robert Audi pośród kilku znaczeń rodzajów intuicji moralnej wymienia intuicje propozycjonalne, takie jak np. samooczywiste twierdzenia etyczne, których prawdziwość może zostać uchwycona na podstawie adekwatnego zrozumienia ich sensu ${ }^{24}$. Michael Huemer uznaje intuicje moralne za intelektualne prezentacje w umyśle ${ }^{25}$. Tak rozumiane intuicje moralne nie mieszczą się w schemacie proponowanym przez Sinnotta-Armstronga i jego kolegów. Wgląd moralny, na przykład, że wykonanie (pod względem ilościowym i jakościowym) takiej samej pracy (w takich samych warunkach ekonomicznych) konstytuuje rację, aby wynagrodzić każdego pracownika w taki sam sposób, albo uchwycenie, że złożenie obietnicy konstytuuje rację moralną, aby tej obietnicy dotrzymać, należą do takiego rodzaju wglądów etycznych, które nie pasują do modelu heurystycznego. Obie wymienione powyżej zasady moralne jawią się jako prawdziwe na mocy intelektualnego wglądu, bez względu na to, czy jesteśmy motywowani emocjonalnie czy nie.

W odpowiedzi na powyższe można by, śladem Cassa Sunsteina, argumentować, że zasady takie, jak: „umów należy dotrzymywać”, "za taką samą pracę należy się taka sama zapłata”, nawet jeśli ich przyjęcie nie jest rezultatem działania heurystyk afektywnych, nadal stanowią przykłady uproszczonych zasad rozumowania. Nawet jeśli zasadniczo pozwalają one identyfikować właściwe decyzje moralne, to stosowane sztywno prowadzą do systematycznych błędów i przez to nadal zasługują na nazwę heurystyk, chociaż innego rodzaju niż heurystyki afektywne.

24 Por. np. R. Audi, Intuition, Inference, and Rational Disagreement in Ethics, „Ethical Theory and Moral Practice”, dz. cyt.

25 M. Huemer, Ethical Intuitionism, dz. cyt. 
Na powyższy argument można odpowiedzieć dwojako. Po pierwsze, można twierdzić, że istnieje fenomenologiczna różnica między „człowieczkiem” skaczącym w naszej głowie i krzyczącym "musisz to zrobić”, który znamionowałby heurystyki, a dostrze$\dot{z}$ eniem na mocy wglądu, że istnieje racja moralna, aby postąpić w określony sposób. Należy jednak przyznać, że nie jest łatwo tę różnicę wyrazić w sposób intersubiektywnie sensowny, bowiem tego rodzaju treści mentalne mają dość prywatny charakter i ich dostrzeżenie wymaga refleksji i pewnej dojrzałości poznawczejej.

Niemniej, na rzecz stanowiska racjonalnego intuicjonizmu etycznego można argumentować w jeszcze inny sposób. Intuicyjnych prawd, takich jak: „umów należy dotrzymywać”, czy „za tę samą pracę należy się taka sama zapłata”, nie należy rozumieć jako sztywnych zasad, które domagają się określonych działań w sposób absolutny. Raczej tego rodzaju zasady moralne należy rozumieć prima facie ${ }^{27}$. Przez zasady (obowiązki) prima facie rozumiem takiego rodzaju zasady (obowiązki), które zawsze stanowią rację do działania w określony sposób, niemniej racje takie w konkretnych okolicznościach mogą zostać przeważone przez inne racje, skłaniające do przeciwnego działania bądź zaniechania działania, do którego skłaniają pierwsze racje. To, co w intuicjach dotyczących zasad prima facie uchwytujemy, nie stanowi ostatecznego rezultatu, wskazania, co w tych a tych okolicznościach ostatecznie powinniśmy zrobić, ale stanowi uchwycenie pewnych normatywnych relacji obecnych pomiędzy poszczególnymi elementami sytuacji. Relacje te mogą zostać wyrażone w postaci zasady, normy (czy obowiązku) ogólnej. Tak rozumiane intuicyjne prawdy moralne (dotyczące zasad lub obowiązków moralnych) nie wymuszają na nas systematycznych błędów, jak to jest w przypadku heurystyk,

26 Nie znaczy to, że to nie jest możliwe, niemniej, w kontekście intelektualnych intuicji moralnych, wedle mojej wied zy, taki satysfakcjonujący opis fenomenologiczny czeka jeszcze na realizację. Interesującą próbę takiego opisu można znaleźć w książce M. Huemera (Ethical Intuitionism, dz. cyt., rozdz. 5).

27 Pojęcie obowiązków prima facie rozumiem tutaj za W.D. Rossem (zob. szczególnie drugi rozdział $z$ tegoż The Right and the Good, Oxford 2002 [1930]). Współcześnie takie rozumienie zasad (obowiązków) moralnych przyjmuje i rozwija Robert Audi (zob. tenże, The Good in the Right..., dz. cyt.). 
ale pozwalają na większą elastyczność w partykularnych sytuacjach. Oczywiście nie oznacza to, że niektóre osoby, nie do końca rozpoznając naturę tych zasad, nie mogą błędnie w sposób sztywny do takich zasad się stosować.

Intelektualne uchwycenie zasad (obowiązków) prima facie należy odróżnić od partykularnych intuicji dotyczących tego, co w danych okolicznościach powinniśmy uczynić. Partykularne intuicje są znaczenie bardziej zawodne niż intuicje dotyczące bardziej abstrakcyjnych relacji normatywnych. Wynika to $z$ faktu większego skomplikowania rzeczywistości moralnej w partykularnych okolicznościach aniżeli poszczególnych relacji moralnych rozważanych in abstracto. Identyfikując jakąśs relację o znaczeniu moralnym (np. relację określonej powinności pewnego rodzaju podmiotu wobec pewnego rodzaju potencjalnego przedmiotu działań, postaw itd.) i dostrzegając jakieś wartości, na których ona jest zawieszona ontologicznie, odcinamy ją w swoim poznaniu od innych relacji moralnych, które mogą z nią współwystępować i komplikować nam obraz. Dzięki abstrakcji przedmiot naszego poznania jest ujęty w pewnej uproszczonej lub wyidealizowanej formie, to pozwala wyraźniej widzieć i identyfikować określone prawdy etyczne. W partykularnej sytuacji, próbując zidentyfikować, co tu i teraz powinniśmy uczynić, musimy objąć swoim poznaniem nie tylko taką wyabstrahowaną relację, ale całą ich sieć, uwzględniając przy tym wiele danych szczegółowych, które dość łatwo pominąć, szczególnie, gdy sytuacja wymaga szybkiego podjęcia decyzji. Musimy wówczas dokonać ważenia czy porównania wielu racji moralnych za bądź przeciw określonemu działaniu, w tym zidentyfikować wiele danych dotyczących pozamoralnych faktów i możliwości. Na przykład zidentyfikować możliwe konsekwencje naszej ewentualnej decyzji, wszystkich potencjalnych „odbiorców” skutków naszego działania, ich pragnień lub oczekiwań, ich, ale i swojej własnej motywacji itd.

Tego rodzaju identyfikacja partykularnej prawdy etycznej także może odbywać się na drodze intuicyjnego wglądu, w którym jednak prawdopodobieństwo błędu jest znacznie większe. Co więcej, w tego rodzaju wglądach, jak można przypuszczać na podstawie badań psychologicznych, szczególnie w warunkach nie- 
pewności dotyczącej wielu, w tym pozamoralnych faktów, często możemy uciekać się do rozumowań heurystycznych. To jednak nie przekreśla faktu, że obok heurystyk w poznaniu moralnym jest obecny element intelektualnych wglądów, które nie pasują do hipotezy heurystycznej proponowanej przez Sinnotta-Armstronga i jego kolegów.

\subsection{Wąskie rozumienie emocji}

Kolejny zarzut, który można wysunąć wobec hipotezy heurystyk afektywnych, dotyczy samego rozumienia emocji i ich wartości poznawczej suponowanych przez Sinnotta-Armstronga i jego kolegów. Sugestię autorów, że emocje nie są wynikiem wcześniejszych sądów moralnych, można zinterpretować jako sugestię, że emocje nie są efektem wcześniejszego poznania faktów moralnych ${ }^{28}$. Autorzy nie bronią ani nie uzasadniają akognitywnej interpretacji emocji, zdają się przyjmować ją jako najbardziej prawdopodobną w świetle współczesnej wiedzy naukowej. Akognitywnie rozumiane emocje są jedynie ewolucyjnie wyselekcjonowanym sposobem reagowania na określone sytuacje, który okazał się korzystny dla przetrwania naszego gatunku, motywował bowiem do działań, które okazały się dla nas zbawienne w skutkach. Na przykład strach każący nam uciekać przed drapieżnikami, gniew wobec tych, którzy nie współpracują, wdzięczność dla tych, którzy czynią nam

28 Sugestię, że emocje moralne nie są efektem wcześniejszego sformułowania sądów moralnych, można interpretować dwojakoः albo, jak przyjmuję w tekście, jako sugestię, że emocje nie są efektem żadnego procesu poznawczego, albo jako sugestię, że emocje nie są efektem stanów doksastycznych (sądów), co nie wyklucza możliwości, że emocje są rezultatem jakichś przeddoksastycznych faz procesu poznania. Zakładam, że autorzy przyjmują pierwszą możliwość, ponieważ uznanie poznawczej wartości emocji moralnych w znaczny sposób osłabiłoby hipotezę heurystyk afektywnych - nie pozwalałoby na wyciąganie wniosku, $\dot{z}$ e intuicje moralne ukształtowane przez emocje (albo nawet $z$ nimi tożsame) nie są wystarczająco wiarygodne, aby stanowić źródło krytyki utylitaryzmu. Także, chociaż być może w mniejszym stopniu, taka interpretacja emocji osłabiłaby twierdzenie, że jeśli emocje są źródłem naszych intuicji moralnych, to nie można mówić o bezpośrednim uchwyceniu własności moralnych. 
dobro motywujące nas do współpracy, obrzydzenie do gnijących substancji, dzięki któremu unikamy ich jedzenia - wszystkie te sposoby reagowania, chociaż, zgodnie $z$ dominującym obrazem naukowym, pojawiły się w nas w wyniku przypadkowych zmian, utrwaliły się w naszym gatunku, ponieważ okazały się korzystne dla osób je posiadających, pozwoliły im przetrwać i rozprzestrzenić swoje geny w ludzkiej populacji.

Autorzy Moral Intuitions w argumentacji za afektywną wersją hipotezy heurystyk moralnych skupiają się na ukazaniu korelacji przyczynowej pomiędzy emocjami a sądami moralnymi formułowanymi przez osoby badane w eksperymentach, na wykazaniu, że to emocje w sposób decydujący determinują sądy moralne, nawet wówczas, gdy same emocje nie mają charakteru moralnego, ale na przykład zostały sztucznie wywołane. Cytują na przykład wyniki badań Thalii Wheatley i Jonathana Haidta, w których podatnym na hipnozę osobom sugerowano w trakcie seansu, aby doświadczały poczucia obrzydzenia, natknąwszy się na określone, moralnie obojętne słowo. Proszeni o ocenę moralną działań zarówno tych moralnie znaczących, jak i moralnie neutralnych, badani dokonywali bardziej surowych ocen, gdy w opisie tych działań zetknęli się ze słowem, które miało wywoływać w nich obrzydzenie ${ }^{29}$.

Krytyczne uwagi, jakie zaproponuję poniżej, dotyczą dwóch zarysowanych powyżej kwestii: kognitywnego charakteru emocji, w tym emocji moralnych, oraz tego, czy $z$ faktu, że możliwa jest manipulacja naszymi partykularnymi sądami moralnymi poprzez wzbudzanie w nas neutralnych moralnie emocji i hipnotyczne sugestie, można wyciągnąć wniosek, że w każdym przypadku sądów moralnych mamy do czynienia $z$ kształtowaniem tych sądów przez nieistotne pod względem moralnym emocje.

A propos akognitywnego ujęcia emocji, nie trzeba eksperymentów, aby dostrzec, że emocje często są wynikiem procesów poznawczych. Na przykład, gdy zlęknę się nagłego ruchu ponad moją głową, ta reakcja emocjonalna wydaje się rezultatem poznania, że po pierwsze zbliża się do mnie jakiś obiekt oraz po drugie

29 Zob. T. Wheatley, J. Haidt, Hypnotic Disgust..., dz. cyt. 
stanowi on dla mnie potencjalne zagrożenie. Ktoś mógłby jednak powiedzieć, zgodnie z zarysowanym powyżej obrazem emocji, że taka reakcja jest jedynie mechaniczną reakcją bez konieczności jakichkolwiek operacji mentalnych, świadomych czy nieświadomych. Chwila refleksji wystarczy jednak, aby zaproponować przykład emocjonalnej reakcji, którą trudno nazwać mechaniczną, gdzie wyraźnie widać, że nasze poznanie (także świadome) ma wpływ na nasze emocjonalne reakcje i w dalszej kolejności na nasze sądy moralne.

Wyobraźmy sobie, że przed wejściem do naszego domu widzimy obcego człowieka pochylonego nad leżącą bliską nam osobą. Szybko dostrzegamy na rękach obcego krew oraz gwałtowne ruchy jego dłoni w okolicach górnej klatki piersiowej, a może nawet szyi bliskiej nam osoby. W okamgnieniu dokonujemy szybkiej oceny sytuacji, interpretacji tego, co się dzieje, i reagujemy gniewem, myślimy bowiem, że jesteśmy świadkami napadu na bliską nam osobę. Gniew wzbiera w nas, cały nasz organizm szykuje się do ataku na obcego agresora. W miarę jednak, jak zbliżamy się do miejsca zdarzenia, dociera do naszej świadomości, że jesteśmy świadkami akcji ratowania życia, nie ataku. Miejsce gniewu szybko zajmuje strach, nadzieja, a później wdzięczność za niesioną pomoc. Procesy kognitywno-afektywne, jakie w nas zachodzą w podobnych sytuacjach, są bardzo złożone i nie jest łatwo określić, który dokładnie czynnik kształtuje nasze emocje, nie jest jednak kontrowersyjne twierdzenie, że nagła zmiana percepcji (i interpretacji) rzeczywistości, czyli tego, jak ujmujemy tę rzeczywistość poznawczo, wpływa na nasze emocje i moralną ocenę ${ }^{30}$.

Akognitywne ujęcie emocji kontrastuje nie tylko $z$ naszym codziennym doświadczeniem, ale także z coraz większą liczbą

30 Wielu autorów przyjmuje kognitywną interpretację emocji. Zob. na przykład S. Roeser, Moral Emotions and Intuitions, dz. cyt.; R. Solomon, Emotions and Choice [w:] Amélie Rorty (ed.), Explaining Emotions, Berkeley-Los AngelesLondon 1980, s. 25I-282; M. Nussbaum, Lover's Knowledge, Oxford I990; R. DE SousA, The Rationality of Emotion, Cambridge, MA i987; L. ZAGZeBSKI, Emotion and Moral Judgment, "Philosophy and Phenomenological Research” 66 (2007), s. 104-I24; D.A. Pizzar ro, P. Bloom, The Intelligence of the Moral Intuitions: Comment on Haidt, „Psychological Review” I Io (2003), s. I93-I96. 
odkryć w ramach tzw. neuronauk, które jak to ujął Peter Railton, ukazują w coraz większym stopniu, że nasz system afektywny, czy też inaczej afektywna część naszych umysłów, to wielowymiarowy i plastyczny system poznawczy, który kieruje naszymi działaniami i decyzjami ${ }^{31}$. Ów system można ująć w kategoriach licznych, częściowo odizolowanych, ale i wielorako powiązanych ze sobą modułów poznawczych, które wyławiają poszczególne aspekty rzeczywistości (w tym, jak się wydaje, także $\mathrm{w}$ aspekcie aksjologicznym) i przesyłają informacje (stanowiące wynik specyficznych dla danych modułów procesów poznawczych) do świadomości w postaci odczuć bądź uczuć, którymi dana osoba może się kierować w swoich świadomych deliberacjach lub decyzjach ${ }^{32}$. Nie są to mechanizmy, które w sposób sztywny, na zasadzie jedynie heurystyk, reagują na dane okoliczności, ale które potrafią się uczyć i aktualizować, w miarę kolejnych doświadczeń dostrajać poznawczo do rzeczywistości33.

Owszem, czasami nasze emocje zamiast wspomagać nasze poznanie, zakłócają je. Nie przekreśla to jednak poprawności kognitywnego modelu emocji. Także fakt, że sztucznie wywołane emocje, które nie mają charakteru moralnego, jak w przypadku emocji obrzydzenia, mogaz generować iluzje widzenia doniosłych moralnie własności, nie oznacza przekreślenia tezy, że emocje stojące u podstaw naszych sądów moralnych są zasadniczo efektem procesów poznawczych. Pomocne tutaj będzie porównanie do percepcji wzrokowej oraz sądów opartych na tego rodzaju percepcji. Bywa czasami, że nasze wrażenia wzrokowe nie są spowodowane przez faktycznie istniejące obiekty, ale halucynacje bądź silne sugestie, na przykład w trakcie hipnozy, lub inne nieistotne, a nawet sta-

31 Zob. P. Railton, The Affective Dog and Its Rational Tale: Intuition and Attunement, „Ethics” I24 (2014), s. 8I3-859.

32 W taki sposób ujmuje intuicje moralne np. John Bolender. Zob. tegoż A Two-Tiered Cognitive Architecture For Mental Reasoning, „Biology and Philosophy” I6 (200I), s. 339-356; także The Genealogy of Moral Modules, „Minds and Machines" I3 (2003), s. 333-355. Więcej na temat koncepcji intuicji moralnych Bolendera pisałem w A. Szutta, Metoda refleksyjnej równowagi. Część II: Zarzut błędnego koła i wiarygodności rozważnych sądów moralnych, „Diametros” 36 (2013), s. I22-I46.

33 Por. P. Railton, The Affective Dog and Its Rational Tale..., dz. cyt. 
nowiące zakłócenie naszego poznania czynniki. $Z$ tego jednak powodu nie twierdzimy, że percepcja wzrokowa jest zasadniczo zawodna i nie powinniśmy się do niej odwoływać w dyskusjach na temat natury świata. Chociaż należy przyznać, że uleganie czasami złudzeniom i iluzjom wzrokowym każe nam zachować pewną ostrożność i krytycyzm wobec tego rodzaju percepcji.

Obrońca hipotezy heurystyk afektywnych mógłby odpowiedzieć, że nie musi przyjmować założenia o całkowitym braku wartości poznawczej emocji. Może przyjąć, że lęk przed wychyleniem się poza krawędź wysokiego urwiska jest racjonalny i zapewne jest skutkiem procesów poznawczych, w ramach których takie działanie zostało ujęte jako niebezpieczne (niosące ze sobą duże prawdopodobieństwo utraty życia lub zdrowia, która z punktu widzenia ewolucji jest niepożądana). Uznanie jednak epistemicznej wartości emocji nie pociąga za sobą uznania, że emocje są efektem ujęcia przez nas (świadomie czy nie) własności moralnych. Zatem, jeśli w oparciu o emocje formułujemy przekonania moralne, a emocje nie są efektem poznawczego kontaktu z własnościami moralny$\mathrm{mi}$, to nadal możemy uważać, że nieuświadomione opieranie się na emocjach w procesie formułowania przekonań moralnych ma charakter heurystyczny.

Wydaje się, że tego rodzaju zarzut opiera się na założeniu, że nie potrafimy odróżnić emocji moralnych, tj. takich, które mają swoje źródło w poznawczym ujęciu własności moralnych, od emocji pozamoralnych, i być może nawet na poziomie fenomenologicznym są one nieodróżnialne. Wówczas dopiero sensowne staje się sugerowanie, że wszystkie nasze emocje mają pozamoralny charakter, a jedynie przez nieuwagę bądź jakiś rodzaj iluzji, której nie potrafimy świadomie zidentyfikować, sugerujemy się emocjami i ulegamy wrażeniu, że uchwytujemy poznawczo fakty moralne i widzimy, że coś jest dobre lub złe moralnie. To założenie wydaje się jednak nieuzasadnione, ponieważ zasadniczo jesteśmy w stanie odróżniać emocje neutralne moralnie od emocji moralnych, chociaż zapewne różne osoby, w zależności od dojrzałości epistemicznej i moralnej, przejawiają tę zdolność na różnym poziomie. Często wystarczy chwila refleksji, aby na przykład odróżnić pozamoralną złość, którą żywię do mojego 
kolegi, za to, że w sporze $z$ innym znajomym nie stanął po mojej stronie, od złości spowodowanej niesprawiedliwym potraktowaniem drugiego człowieka. Zapewne istnieją kwestie, w których nie potrafimy tego rozróżnienia zastosować, na przykład w sporach o moralny status związków homoseksualnych, eutanazji itd., to jednak nie przekreśla sensowności samego rozróżnienia oraz możliwości identyfikowania emocji moralnych oraz odróżniania ich od emocji moralnie neutralnych. Należy też zauważyć, że autorzy eksperymentów, w których sztucznie wywoływano neutralne moralnie emocje, sami zakładali możliwość odróżnienia emocji moralnych od pozamoralnych. Inaczej nie byliby przecie $\dot{z}$ w stanie sformułować wniosku, że pozamoralne emocje także wpływają na formułowanie sądów moralnych.

W ramach zarzutu, że zwolennicy hipotezy heurystyki afektywnej nie doceniają wartości poznawczej emocji, można zwrócić uwagę, że wniosek o zawodności emocji w formułowaniu przekonań moralnych, do jakiego dochodzą w świetle badań empirycznych, często w zasadniczy sposób jest zdeterminowany kontrowersyjnymi założeniami na temat dobra i zła moralnego przyjmowanymi przez prowadzących i powołujących się na badania. Dobrym przykładem potwierdzającym to spostrzeżenie jest interpretacja eksperymentu, w którym badani mają ocenić przypadek rodzeństwa uprawiającego seks, jaką przyjmują proponenci hipotezy heurystyki afektywnej.

W ramach tego eksperymentu, przytoczonego tutaj za Peterem Singerem ${ }^{34}$, badanym zaprezentowano historię Julii i Marka, rodzeństwa spędzającego wakacje na południu Francji. Pewnego wieczoru są oni sami w domku turystycznym w pobliżu plaży. Nudzi im się, więc trochę dla zabicia czasu, trochę dla nowego doświadczenia, decydują się na seks. Używają podwójnego zabezpieczenia (prezerwatywa i pigułka antykoncepcyjna). Samo zbliżenie seksualne okazało się miłym doświadczeniem

34 Por. P. Singer, Ethics and Intuitions, "The Journal of Ethics” 9 (2005), s. 33I-352. Sam eksperyment został przeprowadzony w ramach badań Jonathana Haidta [J. Haidt, F. Björklund, S. Murphy, Moral Dumbfounding: When Intuition Finds No Reason, 2000, niepublikowany manuskrypt; J. HaIDT, The Emotional Dog and Its Rational Tail, dz.cyt.]. 
dla obojga, postanowili jednak, że więcej tego nie uczynią i będą fakt współżycia trzymali w tajemnicy, co sprawia, że czują się sobie jeszcze bardziej bliscy. Po zapoznaniu się z historią Julii i Marka, badani zostali poproszeni o odpowiedź na pytanie, czy uprawianie seksu przez wspomnianą parę było w porządku. Spontaniczne odpowiedzi, jakie padały, były negatywne. Kiedy poproszono badanych, aby je uzasadnili, próbowali oni wskazać, że na przykład Julia i Mark mogli sobie wyrządzić krzywdę, jednak nie byli w stanie określić, na czym konkretnie ta krzywda by polegała. Tak więc autorzy eksperymentu, także Peter Singer, wyciągnęli wniosek, że odpowiedzi badanych były intuicyjne i zdeterminowane przez ewolucyjnie wykształcone emocje, które są nieelastyczne i niezdolne dostosować się do nowych, nieprzewidzianych ewolucyjnie okoliczności, takich jak użycie antykoncepcji.

Założenie, jakie przyjęto w tym eksperymencie, było takie, że postępowanie Julii i Marka było moralnie dopuszczalne. Oparto je na przekonaniu, że stosunek seksualny pomiędzy obojgiem był dobrowolny, oraz wykluczono niepożądany skutek w postaci ciąży (która oprócz tego, że stanowiłaby dla rodzeństwa kłopot sam w sobie, mogłaby ponadto doprowadzić do narodzin chorego genetycznie dziecka). Jednak można zapytać, czy jest oczywiste, $\dot{z}$ e to byłyby jedyne możliwe racje negatywnej oceny moralnej kazirodczego stosunku Julii i Marka. Dlaczego nie założyć, że takich przynajmniej potencjalnych racji jest znacznie więcej? Dlaczego na przykład nie przyjąć, że przekroczenie pewnej bariery psychologicznej, która powstrzymuje rodzeństwo przed podejmowaniem decyzji o zbliżeniu seksualnym, nie sprawi, że pomimo postanowienia nie będą tego więcej robili, w przyszłości powtórzą to przyjemne przecież dla nich doświadczenie, powtórzą wielokrotnie, zwiększając prawdopodobieństwo, że za którymś razem zapomną podwójnie się zabezpieczyć? Po wtóre, dlaczego nie przyjąć, że to doświadczenie będzie miało negatywny wpływ na psychikę obojga bądź przynajmniej jednego z nich, że w wyniku tego zbliżenia utracą (przynajmniej w jakiejś mierze) zdolność do zaangażowania się emocjonalnego w romantyczne związki $z$ innymi osobami? Oczywiście kwestia ewentualnych negatywnych skutków postępowania Julii i Marka nie jest wolna od kon- 
trowersji, odpowiedzi na wysunięte powyżej wątpliwości nie są oczywiste. Wątpliwości te stanowią jednak wystarczający powód, aby dostrzec, że założenie, że wszystko było w porządku (a badani, którzy negatywnie oceniają działanie Julii i Marka, są w błędzie, bo nie umieją podać dobrych powodów swoich wątpliwości), jest przynajmniej kontrowersyjne i przedwczesne. Jeśli tak, to równie przedwczesne i przez to kontrowersyjne jest przyjęcie wniosku, że moralne intuicje i emocje, którymi kierowali się badani w tym eksperymencie, są niewiarygodne poznawczo.

Kończąc część poświęconą zarzutowi nieadekwatnego ujęcia emocji moralnych, można powiedzieć, że hipoteza, wedle której wszystkie intuicje moralne to heurystyki afektywne, byłaby do przyjęcia tylko wówczas, gdyby udało się pokazać, że emocje nie są w żaden sposób powiązane poznawczo $z$ faktami moralnymi, i w związku z tym nie mogą odgrywać roli indykatorów (czy też swoistych reprezentacji) własności moralnych. Chociaż istnieją przypadki, w których emocje okazują się błędne, nieświadomie błędnie zinterpretowane, i przez to wypaczają nasze poznanie moralne, nie wynika $z$ tego, że nie mamy racji, uważając, że zasadniczo emocje (w tym emocje moralne) są elementem procesów poznawczych, w tym także procesów obejmujących poznanie własności moralnych.

\section{Zarys alternatywnej koncepcji poznania moralnego}

W świetle zaprezentowanych w powyższym punkcie wątpliwości można powiedzieć, że hipoteza heurystyki afektywnej nie jest dostatecznie ugruntowana. Wydaje się także, że można mieć wątpliwości co do jej eksplanacyjnej atrakcyjności. Walter Sinnott-Armstrong i jego koledzy podkreślają, że wartość eksplanacyjna ich hipotezy bierze się $z$ faktu, że potrafi ona wyjaśnić takie fenomeny, jak szybkość i łatwość formułowania przekonań moralnych, jak również ich zawodność. Można jednak, jak będę się starał argumentować poniżej, zaproponować alternatywne rozumienie intuicji moral- 
nych, które również przyjmuje, chociaż w nieco zmodyfikowanej formie, ramy teorii dwuprocesualnego umysłu i równie dobrze wyjaśnia wymienione powyżej fenomeny, unikając zarazem słabości hipotezy heurystyk afektywnych, na które wskazano powyżej.

W punkcie poświęconym wąskiemu rozumieniu emocji przez zwolenników hipotezy heurystyki afektywnej odwołałem się do koncepcji Johna Bolendera. Wydaje się, że atrakcyjna eksplanacyjnie koncepcja intuicji moralnych może za swój punkt wyjścia obrać modularny model umysłu, na przykład przykład taki, jaki proponuje John Bolender. Analogicznie do Kahnemana i Tverskiego, Bolender określa swój model mianem dwuwarstwowego systemu, nie definiuje jednak systemu I w terminach sztywnych mechanizmów heurystycznych. Pisze raczej o częściowo odizolowanych mechanizmach neuronalnych, które specjalizują się w wyszukiwaniu i stosowaniu określonych algorytmów, które mogą okazać się pomocne w praktyce. W świetle tego modelu intuicje moralne są rozumiane jako efekt działania takich mechanizmów. Koncepcja modułów, równie dobrze jak hipoteza heurystyk, pozwala zrozumieć zawodność, szybkość intuicji moralnych, jak i to, że procesy leżące u ich podstaw są podświadome i skorelowane z naszymi emocjami.

Dlaczego mechanizmy te są zawodne? Jest to spowodowane wąską specjalizacją i ograniczonym zakresem danych wyjściowych, które uwzględniają bądź do których mają one dostęp. Czym innym jednak jest powiedzieć, że produkują one błędne wyniki $z$ powodu wąskiego zakresu danych, czym innym zaś nazwać je mechanizmami heurystycznymi. Rozwiązanie heurystyczne sugeruje, że nie mamy do czynienia z ujmowaniem własności, które są celem zabiegów poznawczych, ale ujmowaniem jakichś innych własności, które jedynie współwystępują, bez konieczności przyczynowego lub logicznego powiązania, z własnościami docelowymi. Można jednak przyjąć, że analogicznie do modułów percepcyjnych także moduły poznania moralnego dysponują algorytmami identyfikującymi realnie istniejące własności, o czym informują świadomość, komunikując się z nią i generując w niej pewne fenomenalne reprezentacje tych własności.

Przyjęcie, że mechanizmy te pracują na ograniczonej liczbie danych, pozwala też zrozumieć ich szybkość. Ignorowanie całej masy 
danych, a skupienie się jedynie (wyspecjalizowanie) na wąskim ich zakresie, chociaż naraża na błąd, pozwala na szybsze osiągnięcie wyników, co w sytuacjach, kiedy konieczne jest szybkie podjęcie decyzji, może być traktowane jako cecha pożądana. Koncepcja modularna pozwala także zrozumieć, dlaczego przynajmniej część poznania moralnego dzieje się poza świadomością. Mechanizmy poznawcze nie potrzebują do wykonywania swojej funkcji kontroli ze strony systemu 2, muszą się jednak z nim jakoś komunikować, przynajmniej w sytuacji konfliktu wyników poznawczych uzyskanych przez różne (a może i te same) mechanizmy. W tym miejscu pojawia się możliwość wyjaśnienia korelacji naszych reakcji emocjonalnych $z$ naszymi przekonaniami moralnymi. Można bowiem przyjąć za Bolenderem, że emocje (w tym emocje moralne), jakie odczuwamy, są rezultatem komunikowania się mechanizmów wyspecjalizowanych w tropieniu własności moralnych z systemem 2 .

Czytelnik mógłby zauważyć, że jak na razie proponowany tu model niewiele różni się od modelu heurystycznego, $z$ tą jedyną różnicą, że postuluje się tutaj, że strategie obierane przez mechanizmy systemu I mogą być czymś więcej niż strategiami heurystycznymi. To niewiele, aby twierdzić, że taki model ma istotną przewagę nad modelem heurystycznym. Proponuję jednak powiązać koncepcję Bolendera $z$ epistemologią moralną proponowaną w ramach tzw. nurtu racjonalistycznego, który zasadniczo wydaje się kompatybilny $z$ dwuprocesowym modelem umysłu, a stanowi jedynie opis poznania moralnego $z$ innej nieco, bo obejmującej aspekt fenomenologiczny, perspektywy. Można bowiem zauważyć, że pośród mechanizmów systemu I znajdują się nie tylko mechanizmy generujące emocje lub wrażenia percepcyjne, ale również takie mechanizmy, które generują wiele innego rodzaju prezentacji fenomenalnych określanych w literaturze anglosaskiej mianem seemings, do których można zaliczyć także prezentacje intelektualne, w tym intelektualne prezentacje moralne, stanowiące odrębną kategorię od emocji moralnych ${ }^{35}$.

35 Przekonujący opis kategorii seemings wydaje się proponować Michael Huemer [Zob. jego Ethical Intuitionism, dz. cyt., rozdz. 5, a także Chris Tucker (ed.), Seemings and Justification. New Essays on Dogmatism and Phenomenal Conservatism, Oxford 2012]. 
W świetle dwuprocesualnego modelu umysłu nie wydaje się kontrowersyjne przyjęcie następującego rozumienia współpracy systemu I i systemu 2. Uchwycenie poznawcze czy też wglądy dotyczące takich prawd, jak podstawowe prawdy logiki, matematyki, zasady gramatyczne, epistemiczne itd., są przynajmniej częściowo efektem pracy modułów systemu I, który ujawnia się w świadomości w postaci pewnych reprezentacji. Dopiero przyglądając się tym prezentacjom w świadomości, możemy powiedzieć „wydaje mi się, że”, możemy też dokonywać dalszej refleksji. Można powiedzieć również, że owa dalsza refleksja zakłada ciągłą pracę modułów systemu I, modyfikowaną przez procesy, jakie dokonują się w naszej świadomości (systemie 2). Zauważmy, że w trakcie racjonalnej refleksji, obok faktu, że musimy być skupieni i kontrolować, gdzie i w jaki sposób skupiamy swoją uwagę oraz w jaki sposób definiujemy zadania poznawcze świadomości (co jest kosztowne pod względem zużywanej energii mentalnej), mamy też do czynienia z samoistnie pojawiającymi się myślami, pomysłami i innymi treściami mentalnymi, czyli fenomenalnymi prezentacjami. Pojawiają się one, podobnie jak prezentacje percepcyjne i emocjonalne, bezwysiłkowo i spontanicznie. To sugeruje, że mamy tu do czynienia $z$ udziałem samodzielnych, przynajmniej częściowo niezależnych w sposobie działania, mechanizmów systemu I. Tak więc rozsądne jest przyjęcie, że system I wykonuje znacznie większy zakres operacji, niż się może pierwotnie wydawać. Ponadto można przyjąć, że przynajmniej częściowo system I jest wrażliwy na polecenia systemu 2, tj. reaguje na jego polecenia i oczekiwania, a także jego operacje są uzależnione od uwagi i wyników procesów mentalnych na poziomie systemu $2^{36}$. Sposób postrzegania i emocjonalnego reagowania na zdarzenia w otaczającym nas świecie jest ciągle aktualizowany i dostrajany

36 Powyższa uwaga nie przeczy obserwacjom, że przynajmniej niektóre mechanizmy systemu I (w tym mechanizmy emocjonalne) są sztywne, tj. niezależne od tego, jakie są nasze przekonania na poziomie świadomym. Nie dotyczy to jednak tylko modułów poznania moralnego, ale także percepcji zmysłowej, czego dobrym przykładem jest tzw. iluzja Millera-Leyera - co znów nie wystarcza do uznania hipotezy, że percepcja zmysłowa jest zasadniczo oparta na mechanizmie heurystyk. 
(chociaż spostrzeżenie to może się odnosić w różnym stopniu do różnych modułów) do wszelkich sygnałów dotyczących różnorodnych aspektów poznawanej rzeczywistości.

Tak poszerzone rozumienie systemu I i jego interakcji z systemem 2 pozwala na uchwycenie, w jaki sposób proponowany tutaj model może mieć eksplanacyjną przewagę nad modelem heurystycznym. W ramach tego systemu możemy bowiem objąć i połączyć w jeden spójny obraz, obok intuicji moralnych opartych na naszych mechanizmach generujących emocje moralne, także ideę intelektualnych intuicji moralnych (które model afektywnych heurystyk ignoruje). Wydaje się, że współoddziaływanie pomię$\mathrm{d} z y$ elementem intelektualnym a emocjonalnym można opisać $\mathrm{w}$ następujący sposób. Mechanizmy generujące emocje moralne można przypisać szerszej kategorii percepcji moralnej. Brak tu miejsca na dokładne określenie różnicy zakresowej pomiędzy percypowaniem własności moralnych a reakcjami emocjonalnymi odnoszącymi się do tego rodzaju sytuacji. Można jednak powiedzieć, że emocje moralne niosą obok wyrażania naszego stosunku wartościującego (troska, odraza itd.) także pewną informację dotyczącą wartości (dobro, zło, słuszność, niesłuszność) moralnej percypowanej sytuacji ${ }^{37}$. Tego rodzaju percepcja moralna wydaje się mieć charakter partykularny, tj. ujmuje konkretne sytuacje nacechowane określonym ładunkiem moralnym. Pewną racją za takim charakterem percepcji moralnej jest fakt, że informacje ogólne (np. statystyczne opracowania dotyczące ofiar głodu lub wojen na świecie), które w wysokim stopniu abstrahują od nasyconych treścią konkretnych zdarzeń, nie mają takiej zdolności wzbudzania w nas emocji, jak prezentacje konkretnych twarzy cierpiących osób.

Percepcja moralna wydaje się natomiast stanowić pewien punkt wyjścia dla wglądów moralnych natury intelektualnej, które mają bardziej subtelny charakter, jeśli chodzi o aspekt emocjonalny, nato-

37 Mam świadomość, że relacja pomiędzy tym, co nazywam percepcją, a tym, do czego się odnoszę za pomocą terminów „emocje moralne”, domaga się dalszej eksplikacji. Jest to zagadnienie empiryczne, sama analiza pojęciowa i fenomenologiczna mogą nie wystarczyć, aby zaproponować satysfakcjonujący opis tej relacji. 
miast częściej mają charakter ogólny i abstrakcyjny. Jako wglądy abstrakcyjne nie skupiają się na ujęciu całego bogactwa treści poszczególnych sytuacji, ale koncentrują się wokół wybranych aspektów, relacji lub schematów, które są łatwiejsze do treściowego ogarnięcia "okiem świadomego umysłu” i przez to pozwalają na mówienie o faktycznym "wglądzie” bądź zrozumieniu natury danej relacji. Wydaje się zasadne mówienie tutaj o pewnej analogii pomiędzy percepcją wzrokową a abstrakcyjnym uchwyceniem prawd matematycznych. Przy czym warto tutaj zwrócić uwagę na możliwość pewnej stopniowalności w odchodzeniu od konkretnej treści w stronę coraz bardziej ogólnych abstrakcji. Być może tak, jak w przypadku odchodzenia od konkretnych obrazów w stronę pewnych uproszczonych schematów trygonometrycznych, aż do czysto pojęciowego uchwycenia prawd matematycznych reprezentowanych przez trygonometryczne schematy, tak też w przypadku poznania moralnego można by mówić o percepcji konkretnych sytuacji moralnych, w których emocje stanowią istotny element, w stronę coraz bardziej abstrakcyjnych i ogólnych intelektualnych ujęć prawd etycznych.

Powyższy opis alternatywnego względem hipotezy heurystycznej modelu poznania moralnego, choć dość skąpy, posiada jeszcze jedną przewagę eksplanacyjną nad modelem heurystycznym. Nie tylko obejmuje element intelektualny, ignorowany przez zwolenników hipotezy heurystycznej, ale też pozwala zrozumieć, dlaczego intelektualne intuicje moralne mają charakter prima facie oraz dlaczego posiadają pod pewnym względem wyższy status moralny od partykularnych intuicji emocjonalnych (polegający np. na tym, że intelektualne intuicje moralne pozwalają na uchwycenie samooczywistych ogólnych prawd etycznych, zaś partykularnym intuicjom nie można przypisać takiego statusu) ${ }^{38}$.

38 Hipoteza heurystyczna w wersji globalnej nie pozwala na takie porównania, gdyż nie ma w niej miejsca na intuicje moralne innego rodzaju niż heurystyki. Niemniej zwolennicy heurystycznego ujęcia prawd moralnych często przeciwstawiają intuicje moralne przekonaniom moralnym wypracowanym na drodze racjonalnego namysłu, przypisując wyższość epistemiczną tym drugim. Niestety, nie wyjaśniając zadowalająco, w jaki sposób tego rodzaju poznanie moralne jest możliwe. Takie stanowisko zdaje się zajmować na przykład Joshua Greene (zob, tenże, A Secret Joke of Kant's Soul [w:] W. Sinnott-Armstrong (ed.), Moral Psychology, t. I, Cambridge, MA 2008). 
Charakter prima facie intelektualnych intuicji moralnych oraz ich różnica, w tym ta dotycząca statusu epistemicznego, względem partykularnych intuicji moralnych zostały już zaprezentowane. Skupię się zatem jedynie na krótkim powtórzeniu opisu tam zawartego. Partykularne intuicje są znaczenie bardziej zawodne, ponieważ dotyczą bardziej skomplikowanej (bogatej treściowo) rzeczywistości. Identyfikując jakąś abstrakcyjną relację moralną, skupiamy się na dość nieskomplikowanym obrazie, wyidealizowanej formie. To pozwala wyraźniej widzieć i identyfikować określone prawdy etyczne. Natomiast w konkretnych okolicznościach mamy do czynienia $z$ ucieleśnieniem wielu tego rodzaju abstrakcyjnych schematów, przez ustalenie, co w tych okolicznościach powinniśmy uczynić, musimy objąć całą sieć istotnych relacji i schematów, uwzględniając przy tym wiele danych szczegółowych, które dość łatwo pominąć, szczególnie, gdy sytuacja wymaga szybkiego podjęcia decyzji, a które ponadto często domagają się przeciwstawnych decyzji. Musimy wówczas dokonać ważenia czy porównania wielu racji moralnych, za bądź przeciw określonemu działaniu. Im bardziej skomplikowana konkretna sytuacja, tym większe prawdopodobieństwo, że coś pominiemy ('świadomie lub nie) i popełnimy błąd.

Jest nawet możliwe uznanie, że czasami nasze partykularne „wglądy”, jeśli nie dysponujemy odpowiednimi cnotami epistemicznymi (uważnością, spostrzegawczością, doświadczeniem, bezstronnością itd.) ${ }^{39}$, mogą być wynikiem nieświadomego zastosowania strategii heurystycznych, w tym także heurystyk afektywnych, co na przykład tłumaczyłoby, dlaczego w niektórych eksperymentach badani wyrażali sądy etyczne w oparciu o emocje, które były pozbawione moralnego charakteru.

Należy jednak przynajmniej zauważyć, że chociaż zjednej strony można mówić o niższym statusie epistemicznym partykularnych intuicji moralnych niż intuicji intelektualnych, $z$ drugiej strony tego

39 Zagadnienie cnót epistemicznych jest bardzo szerokie i samo w sobie zasługuje na oddzielną analizę, niestety, ze względu na ograniczone rozmiary artykułu, nie mogę się nim tutaj zająć w sposób satysfakcjonujący. Niemniej mam świadomość, że rozwinięta koncepcja intuicji moralnych powinna objąć także zagadnienie cnót epistemicznych. 
rodzaju partykularne wglądy są w pewnym sensie epistemicznie pierwsze, służą bowiem jako doświadczeniowa podstawa, na której dopiero jesteśmy w stanie dokonywać wglądów intelektualnych bądź te wglądy korygować, podstawa, do której możemy się odwoływać w krytycznej analizie wglądów ogólnych. Wglądy ogólne również są traktowane jako omylne, a ich status epistemiczny można poprawiać poprzez zestawianie ich i harmonizowanie $z$ wglądami partykularnymi w ramach dążenia do refleksyjnej równowagi.

Brak miejsca i czasu, aby bardziej szczegółowo zaprezentować powyższą alternatywę dla hipotezy heurystyki afektywnej, niemniej już na podstawie tej wstępnej charakterystyki widać, że taki model jest obiecujący. Jest w stanie wyjaśnić zarówno szybkość, spontaniczność, jak i zawodność intuicji moralnych równie dobrze jak model heurystyczny, a ponadto, czego model heurystyczny już nie proponuje, daje możliwość objęcia innych rodzajów intuicyjnego poznania moralnego niż to oparte na emocjach.

\section{Wnioski}

W świetle powyższych rozważań, wydaje się, że intuicji moralnych nie można satysfakcjonująco wyjaśnić przez odwołanie do pojęcia heurystyki podstawiania. Po pierwsze, hipoteza proponowana przez Waltera Sinnotta-Armstronga, Liane Young i Fiery'ego Cushmana wymaga odpowiedniej motywacji, tj. podstaw, aby uważać, że oparte na moralnych intuicjach przekonania są wysoce zawodne. Po drugie, koncepcja intuicji moralnych jako przekonań moralnych określonych w sposób decydujący przez nasze emocjonalne reakcje zbyt wąsko ujmuje zjawiska, które mogą podpadać pod nazwę intuicji moralnych. Ignoruje się tu bowiem możliwość intelektualnego wglądu w prawdy moralne. Po trzecie, samo rozumienie emocji, leżące u podstaw tej hipotezy, także jest kontrowersyjne, traktuje się tu bowiem emocje jako pozbawione wartości poznawczej mechaniczne sposoby reagowania, odmawiając im wartości poznawczej. Ponadto wartość eksplanacyjna 
hipotezy heurystycznej nie jest tak atrakcyjna, jak sugerują jej autorzy. Można bowiem zaproponować alternatywną koncepcję, która równie dobrze wyjaśnia te same fenomeny co hipoteza heurystyczna, a jednocześnie unika problemów tej drugiej, które wskazano w punkcie 5 .

Powracając do kwestii, od której rozpoczęliśmy nasze rozważania dotyczące hipotezy heurystycznej, tj. debaty między sytuacjonizmem a etyką cnót, można powiedzieć, że zwolennicy sytuacjonizmu nie mogaz się spodziewać pomocy ze strony hipotezy heurystyk afektywnych. Analiza tego, w jaki sposób intuicyjnie uchwytujemy prawdy moralne, nie tylko nie wspiera stanowiska sytuacjonistycznego, ale wręcz zdaje się dawać argumenty do ręki zwolennikom etyki cnót. Stwarza bowiem możliwość obrony stanowiska, że podmiot moralny jest w stanie świadomie poznawać fakty moralne i kierować się tą wiedzą w swoich decyzjach. Co więcej, wydaje się nawet, czego jednak nie będę tutaj szerzej argumentował, że zarysowana powyżej epistemologia moralna daje wsparcie dla Arystotelesowskiej koncepcji emocji, które po odpowiednim treningu mogą pozytywnie wspierać cnotliwe osoby $\mathrm{w}$ bardziej niezawodnym poznaniu i działaniu moralnym ${ }^{40}$.

\section{Bibliografia}

Audi R., The Good in the Right. The Theory of Intuition and Intrinsic Value, Princeton: Princeton University Press, 2004.

Audi R., Intuition, Inference, and Rational Disagreement in Ethics, „Ethical Theory and Moral Practice" II (2008), s. 475-492.

Bolender J., A Two-Tiered Cognitive Architecture For Mental Reasoning, „Biology and Philosophy” I6 (200I), s. 339-356.

Bolender J., The Genealogy of Moral Modules, „Minds and Machines” I3 (2003), s. 333-355.

Brink D., Moral Realism and the Foundations of Ethics, Cambridge: Cambridge University Press, 1989.

40 Do takiej konkluzji na temat najnowszych badań dotyczących roli systemu I w poznaniu moralnym dochodzi na przykład Peter Railton w cytowanym już tutaj artykule (zob. tenże, The Affective Dog and Its Rational Tale..., dz. cyt.). 
Carlsmith K. i in., Why do we Punish? Deterrence and Just Deserts as Motives for Punishment, "Journal of Personality and Social Psychology" 83 (2002), s. 284-289.

Ciaramelli E. i in., Selective Deficit in Personal Moral Judgment Following Damage to Ventromedial Prefrontal Cortex, „Social Cognitive Affective Neuroscience” 2 (2007), s. 84-92.

Cushman F., Young L., Hauser M., The Role of Conscious Reasoning and Intuition in Moral Judgments: Testing Three Principles of Harm, „Psychological Science” I7 (2006), s. I082-I089.

Haidt J., The Emotional Dog and Its Rational Tail, „Psychology Review” IO8 (200I), s. 8I4-834.

Haidt J., Björklund F., Murphy S., Moral Dumbfounding: When Intuition Finds No Reason, 2000, niepublikowany manuskrypt.

Hauser M., Young L., Cushman F., Reviving Rawls' Linguistic Analogy: Operative Principles and the Causal Structure of Moral Action [w:] W. Sinnott-Armstrong (ed.), Moral Psychology, Volume 2: The Cognitive Science of Morality, Cambridge, MA: MIT Press 2008, s. I07-I43.

Huemer M., Ethical Intuitionism, Basingstoke-New York: Palgrave Macmillan, 2005.

Greene J.D., A Secret Joke of Kant's Soul [w:] W. Sinnott-Armstrong (ed.), Moral Psychology, t. I, Cambridge, MA: MIT Press 2008.

Greene J.D. i in., Cognitive Load Selectively Interferes with Utilitarian Moral Judgment, „Cognition” I07 (2008), s. II44-II54.

Kahneman D., Pułapki myślenia. O myśleniu szybkim i wolnym, tłum. P. Szymczak, Poznań: Media Rodzina, 2012.

Kahneman D. i in,, Shared Outrage and Erratic Rewards: The Psychology of Punitive Damages, "Journal of Risk and Uncertainty" I6 (I998), s. 49-86.

Kahneman D., Shane F., A Model of Heuristic Judgement [w:] K. Holyoak, R.G. Morrison (eds.), The Cambridge Handbook of Thinking and Reasoning, Cambridge: Cambridge University Press, 2005, s. 267-292.

Koenigs M. i in., Damage to the Prefrontal Cortex Increases Utilitarian Moral Judgments, „Nature” 446 (2007), s. 908-9I I.

Mackie J., Ethics. Inventing Right and Wrong, London: Penguin Books I977.

McBrayer J.P., A Limited Defense of Moral Perception, „Philosophical Studies" I49 (2010) 3, s. 305-320. 
Mendez M.F., Anderson E., Shapira J.S., An Investigation of Moral Judgment in Frontotemporal Dementia, "Cognitive Behavioral Neurology" I8 (2005), s. 193-I97.

Mikнail J., Aspects of a Theory of Moral Cognition: Investigating Intuitive Knowledge of the Probibition of Intentional Battery and the Principle of Double Effect, maj 2002, ssrn.com/abstracts $=762385$.

Myers D.G., Intuicja. Jej siła i słabość, tłum. A. Sosenko, Wrocław: Moderator, 2004.

Nussbaum M., Lover's Knowledge, Oxford: Oxford University Press, I990.

Pizzarro D.A., Bloom P., The Intelligence of the Moral Intuitions: Comment on Haidt, "Psychological Review” I Io (2003), s. 193-196. Railton P., The Affective Dog and Its Rational Tale: Intuition and Attunement, „Ethics” I24 (2014), s. 813-859.

Roeser S., Moral Emotions and Intuitions, Basingstoke-New York: Palgrave Macmillan, 20II.

Ross W.D., The Right and the Good, Oxford: Clarendon Press, 2002 (1930).

Schnall S. i in., Disgust as Embodied Moral Judgment, „Personality and Social Psychology Bulletin" 34 (2008), s. I096-II09.

Singer P., Ethics and Intuitions, "The Journal of Ethics" 9 (2005), s. 33I-352.

Sinnott-Armstrong W., Reflections on Reflection in Robert Audi's Moral Intuitionism [w:] M. Timmons, J. Greco, A.R. Mele (eds.), Rationality and the Good. Critical Essays on the Ethics and Epistemology of Robert Audi, Oxford: Oxford University Press, 2007, s. I9-30. Sinnott-Armstrong W., Young L., Cushman F., Moral Intuitions [w:] J.M. Doris i in. (eds.), The Moral Psychology Handbook, Oxford: Oxford University Press, 2010, s. 246-272.

Solomon R., Emotions and Choice [w:] A. Rorty (ed.), Explaining Emotions, Berkeley-Los Angeles-London: University of California Press, I980, s. 25I-282.

DE Sousa R., The Rationality of Emotion, Cambridge, MA: MIT Press, I987.

Sunstein C.R., Moral Heuristics, „Behavioral and Brain Science” 28 (2005), s. 53I-573.

Szutta A., Metoda refleksyjnej równowagi. Część II: Zarzut błędnego koła i wiarygodności rozważnych sąów moralnych, „Diametros” 36 (2013), s. I22-I46. 
Tucker C. (ed.), Seemings and Justification. New Essays on Dogmatism and Phenomenal Conservatism, Oxford: Oxford University Press, 2012. Wheatley T., Haidt J., Hypnotic Disgust Makes Moral Judgments More Severe, „Psychological Science” I6 (2007), s. 780-784. Valdesolo P., DeSteno D., Manipulations of Emotional Context Shape Moral Judgments, „Psychological Science” I7 (2006), s. 476-477.

Zagzebsei L., Emotion and Moral Judgment, "Philosophy and Phenomenological Research" 66 (2007), s. I04-I24.

\section{Key words Abstract}

moral The paper offers critical analysis of the hypothesis put emotions, forward by Walter Sinnott-Armstrong, Liane Young, and virtue Fiery Cushman, according to which moral intuitions are ethics, merely affective heuristics. After a short presentation

heuristics, of the concept of heuristics, as well as the arguments moral underlying the heuristic hypothesis, I formulate three intuitions, counter-arguments, which aim to show that the heuristic situationism, hypothesis is not sufficiently grounded, and what is more, Walter it is based on both too a narrow understanding of moral Sinnott- intuitions and acognitive concept of moral emotions. The -Armstrong criticism is supported with an alternative, positive outline of how one could understand moral intuitions. The whole argumentation presented in the paper is treated as a voice in the debate between virtue ethics and situationism, a voice which is to support virtue ethics.

Artur Szutta - doktor filozofii, pracuje w Instytucie Filozofii, Socjologii i Dziennikarstwa Uniwersytetu Gdańskiego. Interesuje się metaetyką, etyką i filozofią społeczną. Autor między innymi książki Obywatelskie niepostuszeństwo. Próba okréslenia pojęcia (Wydawnictwo Naukowe Semper, Warszawa 20II), serii artykułów poświęconych metodzie refleksyjnej równowagi („Diametros”35, 36, 37, 2013) oraz artykułu Authentic Civic Attitude: A Personalist Perspective [„American Catholic Philosophical Quraterly" 86 (2012)]. Adres e-mail: aszuttaio2@gmail.com.

Artykuł został napisany w ramach realizacji projektu badawczego finansowanego przez Narodowe Centrum Nauki nr 2012/07/B/HSI/or607. 